\title{
Pollutants of Fish Processing Industry and Assessment of its Waste Management by Wastewater Quality Standards
}

\author{
Setia Devi Kurniasih ${ }^{1}$, Tri Edhi Budhi Soesilo ${ }^{1, *}$, and Roekmijati Soemantojo ${ }^{1}$ \\ ${ }^{1}$ School of Environment Science, Universitas Indonesia, Indonesia.
}

\begin{abstract}
The aim of this research was to evaluate the waste management by analysing pollutants produced by the Fish Processing Industry (The XYZ Company). Field observations were carried out to see the conditions of management. While, wastewater samples were carried out in each production process. The method of analysis was covered by the conditions of waste management, and the quality and quantity of wastewater that assed based on waste quality standards for the Fish Processing Industry. The results showed that waste management at XYZ Company has not been done optimally. This is indicated by the wastewater directly only through the sewerage and it is not possible to utilize waste. In addition, the parameters of wastewater are above the wastewater quality standards. It showed the parameters of $\mathrm{BOD}_{5}$ and $\mathrm{COD}$ in the melting process $(566.67 \mathrm{mg} / \mathrm{l}$ and $1,790 \mathrm{mg} / \mathrm{l})$, cooking $(971.67 \mathrm{mg} / \mathrm{l}$ and $1022.33 \mathrm{mg} / \mathrm{l})$, and washing $(788.33 \mathrm{mg} / \mathrm{l}$ and $2.518 \mathrm{mg} / \mathrm{l})$. In addition, the parameters of BOD 5 and COD waste load in the cooking process $(1.397 \mathrm{~kg} /$ tonnes of raw material and $3.008 \mathrm{~kg} /$ tonnes of raw material) and washing $(2.564$ $\mathrm{kg} /$ tonnes of raw material and $8.684 \mathrm{~kg}$ /tonnes of raw material). The management improvement can encourage the ustainability of water and sanitation for all.
\end{abstract}

Keywords: Fish Processing Industry, Pollutant, Waste Management, Waste Minimization

\section{Introduction}

Indonesia has a considerable number of fishery industries and concentrated in several special locations, one of them is at the Fishing Port of Nizam Zachman Jakarta (FPNZJ). The harbor serves not only fisheries activities, but also has a modern industrial function as a center for processing fish, shrimp, and other marine products [14]. As an integrated fishery area, fishery production in FPNZJ continues to increase with an economic turnover of IDR 23.6 Billion per day [10]. On the other hand, the increase in production is not directly proportional to the amount of waste produced.

Environmental problems caused by industrial activity have become one of the important issues. The industry not only fulfills the best performance in the economic aspect, but is also required to be more environmentally and socially responsible [13]. This requires an effective strategy to develop an industry balanced with environmental conservation. Fishery waste contains high organic compounds, namely Biochemical Oxygen Demand (BOD), Chemical Oxygen Demand (COD), nitrogen, oil and fat, and salt [2]. Based on this, liquid waste fish processing industry has the potential to pose a threat to human health and pollute the environment, because it is easily degraded by microorganisms [3]. Given this condition, the fish processing industry needs to have an understanding of waste management as an effort to control pollution.

The efforts to control environmental pollution have actually been done through various efforts through environmental regulations and programs [5]. However in reality, these efforts are often ignored, whereas control of environmental pollution becomes one of the important efforts to restore environmental conditions. Generally, companies only focus on business aspects only, such as delivery dimensions, quality, and cost [7]. To meet the sustainability needs of the fish processing industry, it is necessary to apply the principle of waste minimization.

Waste minimization is one of the best approaches to meet the sustainability of waste management in the fish processing production process. The waste minimization approach falls into the principle of Cleaner Production. According to United Nations Environment Programme, Cleaner Production (PB) is defined as a sustainable integrated environmental impact prevention strategy for processes, products and services to improve overall efficiency and reduce risks to people and the environment. The purpose of applying this concept is to increase the efficiency of natural resource use, to prevent environmental pollution, and to reduce the formation of waste at the source [12]. Therefore, the success of the waste management system needs to be evaluated in order to achieve aspects of excellence and customer satisfaction, in order to comply with environmental standards and regulations such as ISO 14001 and Eco-labeling. Based on this, the research is conducted to analyze the waste management system as an effort to minimize waste in XYZ Company Industrial.

\footnotetext{
* Corresponding author: soesilo@indo.net.id
} 


\section{Materials and Methods}

This study was located at Fish Processing Industry Area of Fishing Port of Nizam Zachman Jakarta - North Jakarta (XYZ Company). The most important parameters in wastewater from fish processing industry are $\mathrm{pH}, \mathrm{BOD}_{5}$ (Biochemical Oxygen Demand), COD (Chemical Oxygen Demand), FOG (Fats, Oil and Grease), TSS (Total Suspended Solid), Ammoia, Sulfide, and Free Chlorine. The effluent values are average of at least 3 samples taken at arbitrary times. The effluent concentrations of $\mathrm{BOD}_{5}, \mathrm{COD}, \mathrm{FOG}, \mathrm{TSS}$, Ammonia, Sulfide, and Free Chlorine were analyzed according to Standard Methods (APHA, 1998). The waste management were analyzed by field observation. Furthermore, the result of effluent values and waste load will be compared with the quality standard of the fish processing industry.

\section{Results and Discussions}

\subsection{Analysis of Fish Processing Industry Activities of XYZ Company on Wastewater Management System}

This section discusses the activities undertaken by the industry in waste management in the presence of management policies on wastewater (liquid and solid waste). Based on the results of a field survey of industry, the Company XYZ is a fish processing industry with main raw material is Skipjack Tuna. Fish production is done once a day with an average production of about $8-10$ tons per day. The products are marketed in the form of loin, where the number of products produced an average of about $30 \%-33 \%$ of the raw materials used. Fish production is based on market demand, where most products are exported to Asian countries, Australia and other countries.

Phase of fish processing process is thawing, butchering (if measuring 5-8 $\mathrm{kg}$ per fish) or cutting fish (cutting into $2-4$ parts if size $>10 \mathrm{~kg}$ per fish), steaming (for 40-130 minutes according to fish size), skinning (the head, fish bones, and skin), cleaning (thorns and redmeat), packing, freezing, and storage (if not directly delivered). During the processing of the product, it indicates the presence of both solid and liquid waste. The development of the fishery industry not only gives positive impacts of economic improvement and employment, but also negatively impacts waste [8]. Identification of fish processing industry waste of XYZ Company can be seen in Table 1.

Based on Table 1 shows that liquid waste in fish processing industry of The Company XYZ comes from thawing, cooking, and tool and floor cleaning process. Liquid waste generated from the production process is expected to still be utilized, because of the potential to produce fish oil derived from the steaming process. However, it should be noted that liquid waste that can be utilized just only come from the thawing and cooking process. The utilization is carried out by separating from each of waste. Which, thawing process can be reused for same process with water recycling systems [1]. While cooking process can be used for raw material of new product, because waste from the cooking process still contains fish oil. In addition, the results of solid waste are the head, bone, skin, red meat, and plastic used derived from the process of cleaning, skinning, and packaging process. In order to reduce waste, solid waste can be reused for raw material for new product (as well as liquid waste from the cooking process).

Waste from the production process is average disposed of into waste that unvaluable. It can even be a material of environmental pollution in the form of unpleasant odor, if not handled properly. This is explained that waste from the fish and shrimp processing industry has an effect on the surrounding environment [9]. Waste generated from fish processing can have adverse impact on the environment, if not treated properly [16]. Liquid wastes from steam yields can be a source of fish oil, whereas solid waste from meat removal results has the potential to be a relatively safe source of calcium and phosphorus. It is indicated that reprocessing of solid waste fish can be used as source of raw material for the manufacture of fish meal [6].

Table 1. Identification of Fish Processing Industry Waste of XYZ Company.

\begin{tabular}{|c|l|c|l|}
\hline No. & \multicolumn{1}{|c|}{ Waste } & Type & \multicolumn{1}{c|}{ Process } \\
\hline 1 & Thawing water & Liquid & Thawing \\
\hline 2 & Steaming water & Liquid & Cooking \\
\hline 3 & Heads and bones & Solid & Cleaning \\
\hline 4 & Skins and red meats & Solid & Skinning \\
\hline 5 & Thorns & Solid & Skinning \\
\hline 6 & Plastic used & Solid & Packaging \\
\hline 7 & Washing tool and floor water & Liquid & Tool and floor cleaning \\
\hline
\end{tabular}

\subsection{Quality Analysis of Waste Source Fish Processing Industry of XYZ Company}

To manage wastewater, it is important to know the quality of wastewater produced. This is important because pollution from wastewater, effects of temperature, toxic and radiological effects, pathogen dangers, siltation, and salinity in water [4]. The identification of liquid waste quality shows that fish processing industry at XYZ Company contains high organic compounds (Table 2). This is in line with the statement of number [2] that the quality of liquid waste fish 
processing industry contains high organic compounds, such as BOD, COD, nitrogen, oil, fat, salt, and other organic materials. The quality is measured in accordance with environmental quality standard Liquid Waste Quality Standard of Fish Processing Industry Activities [11].

Based on Table 2, it is known that the parameters of BOD and COD exceed the quality standards of both the concentrations and waste loads determined. The quality standard used to analyze the quality of waste is the quality standard of fish canning industry. The use of quality standard based on type of fish processing industry at XYZ Company is precooking, where the process of such activities belongs to the canning industry. BOD and COD concentration on the result of field measurement is known 7 times higher than quality standard of wastewater concentration. While, pollution loads 2 times more than quality standard of wastewater load. Seeing this, it can be concluded that the wastewater of fish processing industry is potentially contaminated with high BOD and COD.

Table 2. Concentrations and Waste Loads of the Fish Processing Industry of XYZ Company.

\begin{tabular}{|c|c|c|c|c|}
\hline Parameter & $\begin{array}{c}\text { Concentrations } \\
(\mathbf{m g} / \mathbf{L})\end{array}$ & $\begin{array}{c}\text { Quality Standards of } \\
\text { Wastewater } \\
\text { Concentrations (mg/L) }\end{array}$ & $\begin{array}{c}\text { Waste Loads } \\
\text { (kg/ton } \\
\text { product) }\end{array}$ & $\begin{array}{c}\text { Quality Standards of } \\
\text { Wastewater Load } \\
\text { (kg/ton product) }\end{array}$ \\
\hline BOD 5 & 500 & 75 & 2.7 & 1 \\
\hline COD & 1056 & 150 & 5.702 & 2 \\
\hline TSS & 57 & 100 & 0.307 & 1 \\
\hline Ammonia & 1.1 & 5 & 0.005 & 0.3 \\
\hline FOG & 8 & 15 & 0.043 & 0.15 \\
\hline Sulfide & 0 & 1 & 0 & 0.01 \\
\hline Free Chlorine & 0.32 & 5 & 0.0017 & - \\
\hline
\end{tabular}

\section{Conclusion}

The waste management at XYZ Company is not yet optimal. Certain pollutants in fish processing industry are more important to target for pollution prevention than others. However, parameters of fish processing industry have highly organic content, therefore $\mathrm{BOD}_{5}$ and $\mathrm{COD}$ are important parameters to pollution control. The effluent values $\left(\mathrm{BOD}_{5}\right.$ and $\mathrm{COD}$ ) that exceed the quality standard are from thawing, cooking, and washing process. While waste loads (BOD 5 and COD) that exceed the quality standard are from cooking and washing process. In addition, the utilization of solid waste in the form of head, bone, red-meat can be reprocessed for the manufacture of fish meal. Furthermore, the utilization of liquid waste can be reused for the same process. The utilization of solid and liquid waste can reduce pollution, so as to prevent environmental pollution. It can be on the waste management in the fish processing industry to reduce pollution.

\section{Acknowledgments}

This research was funded by the Grant of Indexed International Publication for Final Project of Students/Publikasi Terindeks Internasional untuk Tugas Akhir Mahasiswa (PITTA) Universitas Indonesia 2018 with contract number 2586/UN2.R3.1/HKP.05.00/2018.

\section{References}

1. E. Alkaya, G.N. Demirer. MAVSPW. Food and Bioprod Process. 1 (2016)

2. A.S.M. Ammar, (Rev) FPW: CTU, J. Agr. Vet. Sc. 7,1 (2013)

3. R.O. Cristóvão, C.M.S. Botelho, R.J.E. Martins, R.A.R.Boaventura, CBTFCW. Int. J. Biosc. Biochem. and Bioinfr. 2, 4 (2012)

4. W.W. Eckenfelder, W.N. Hansard, $U W Q M(T \& A)$ (DEStech Publications, Inc, Pennsylvania, 2004)

5. P. Gintings. P\&CIP (Pustaka Sinar Harapan, Jakarta, 1995)

6. H. Harris , D. Efreza, dan I. Nafsiyah. J. Hum Dev. 6, 3 (2012)

7. S. Hasibuan. J. Env. Tech. 1, 1 (2000)

8. B. Ibrahim. Rev: Bio WTS FPP w. Actv. Sludge. Tech. Bul. Fish. Prod. 8, 1 (2005)

9. S. Islam, S. Khan, M. Tanaka. WL S\&F Proc.: Pot. Src of Haz. The Coast\&Nearshr Envi. Mar. Poll. Bul. 49 (2004)

10. F. Kharisma, Syaifuddin, J. Zain. Distri. FPNZJ In The Fish. Sec. of Jakarta Prov. (Repository of Fishery/Aquatic, Universitas Riau, 2013)

11. Regulation of Environment Minister No. 5 (2014) about Quality Standards Liquid Waste Fish Processing Industry. 
12. R. Rizal. Manag. of Ind. Eco., Dev. of Sust. Ind. Sys\&Envi. Awarn (UI-Press, Jakarta, 2013)

13. M.F. Salvado, S.G. Azevedo, J.C.O. Matias, L.M. Ferreira. Prop. Sust. Indx. Auto. Ind. Sust. J. 7: (2015)

14. A.R. Sam, S.H. Wisudo, B. Murdiyanto, B.H. Iskandar. Dev. Strat. FPNZJ as a Fish Mark. Cent. Mar. Fish. 2, 2 (2011)

15. Syahrul, Dewita. Eff. Minim. Imp. Env. Poll. SW Proc. Catfish at Dist. Kampar. (Nat. Sem. Proc. "Environmental Conservation and Disaster Mitigation, 2016)

16. M. Thrane, E.H. Nielsen, P. Cristensen. Clean. Prod. in Danish Fish Proc. - Exper, Stat. Poss. Fut. Strat. J. Clean. Prod. 17 (2009) 